\title{
FAMILY SUPPORT TO ADOLESCENTS WITH THALASSEMIA
}

\author{
Dewi Rejeki ${ }^{1}$, Yuli Utami ${ }^{2 *}$, Sari Narulita ${ }^{3}$ \\ 1. Faculty of Nursing and Midwifery, Universitas Binawan, Jakarta-Indonesia. \\ 2. Faculty of Nursing and Midwifery, Universitas Binawan, Jakarta-Indonesia. \\ 3. Faculty of Nursing and Midwifery, Universitas Binawan, Jakarta-Indonesia.
}

*Correspondence: Yuli Utami | Universitas Binawan | ysaliman@ gmail.com

\begin{abstract}
Introduction: Thalassemia is one of the genetic disorders characterized by the decrease or absence of one of the globin chains, either alpha chain or beta chain. Which are the main components of normal hemoglobin. Thalassemia has become serious health issue in Mediterranean, Middle East, India, and South East Asia, including Indonesia. The thalassemia gene frequency in Indonesian population ranging from 3-8\%. Adolescent is the transition period from children to adult. Thalassemia adolescents express psychosocial reaction and unpleasant experience due to the lifetime treatment routines that they must face off. These impact on the adolescents' family and self-esteem. This study aims to analyze the relationship between family support and self-esteem of thalassemia adolescents.

Method: This was a quantitative study design with phenomenology approach. A total of 50 subjects were collected with purposive sampling technique. Data were obtained by from questionnaire and analyzed using Spearman Rho method with cross sectional approach.

Results: The statistical result with Spearman Rho method shows significant $\mathrm{p}$ value of $0.024(\mathrm{p}<0.05)$ and $\mathrm{r}$ value of 0.319. The positive correlation implies that both variables are moving in same direction with weak relationship. These results are in accordance with the hypothesis that family support are related with self-esteem of thalassemia adolescents.

Conclusion: Family support in thalassemia adolescents is high and no thalassemia adolescents present with low selfesteem, mostly normal. The correlation between these two variables is weak but significant.
\end{abstract}

Keywords: Family Support, Self-Esteem, Adolecents of Thalassemia.

Received October 29, 2021; Accepted December 30, 2021

\section{INTRODUCTION}

Thalassemia is one of the genetic disorders characterized by the absent formation or reduction of one of the globin chains, either the alpha or beta chain, which are the main preparation component of the normal hemoglobin molecules. World Health Organization (2001) reports that 7\% of the total world population carries the thalassemia trait (carrier/minor), and 300,000-400,000 children were born with major thalassemia. Approximately 3-8\% of Indonesians carry the Thalassemia gene, and its incidence is high. According to (Wahidiyat, 2018), this condition is seen from the frequency of the abnormal gene. Thalassemia tends to spread to Italians, Greeks, Middle East people, Asians, and Africans. However, it is estimated that the number of thalassemia patients in Indonesia will reach 20,000-25,000 cases in 2028. Data from the medical record of RSCM Kiara (2017) showed 264 adolescent patients aged 10 to 18 years old who had thalassemia.

Adolescence is the age of the transition from childhood to maturity. In the profession of doctor and nursing care, adolescents up to 18 years old are treated by pediatricians and child's nurses in pediatric care units. (Wahidiyat, 2018) explains that the management principles for children with thalassemia are a routine transfusion with the pre-transfusion $\mathrm{Hb}$ target of $9 \mathrm{~g} / \mathrm{dl}$, daily iron chelation consumption, regular monitoring, and psychosocial assistance. Sulastri and Titi (2018) add that parent involvement in family support for thalassemia child care is necessary because older people also nurse children suffering from chronic diseases.

A preliminary study was conducted in the Kiara thalassemia transfusion room at Dr. Cipto Mangunkusumo Hospital (RSCM). It is a room where thalassemia patients and other patients perform a blood transfusion. Patients with major thalassemia who perform transfusions regularly frequently show a psychosocial reaction and bad experiences. Like other teenagers, they cannot face their problems alone due to several reasons. 1 . They disobey the regular medical check-up, and thus, they always come to the hospital with low $\mathrm{Hb}$ (hemoglobin) under $5 \mathrm{~g} / \mathrm{dl}$. 2. They have self- denial that they have been teenagers but do not 
have self-reliance as a teenager. 3. Some adolescent thalassemia patients do not want to socialize with other adolescent thalassemia patients. 4. Parents sometimes do not accompany their children to the regular medical check-up. Consequently, the children take crucial decisions with the parents of other patients who know them. 5. Some adolescent thalassemia patients have low and less positive self-esteem. (Albaroroh, 2016) explain that such conditions occur because adolescents face various issues that they cannot solve without guidance and support from the closest people. The thalassemia disease impacts physical and psychosocial conditions, and children with chronic illness easily experience emotions and behavior problems.

Maghfiroh (2014) investigated the self-esteem of adolescents aged 14-21 years and discovered that $61 \%$ of the component of the feeling of competence was assessed with low self-esteem low; thus, health workers necessarily help patients identify positive aspects and capabilities. The interview results of (Dewijayanti, 2018) show that physical conditions that frequently and suddenly decrease, compassion accepted, and family support help thalassemia patients develop their spirit and recreate positive thoughts. Meanwhile, (Mulyani \& Fahrudin, 2011) revealed that patients with major thalassemia and regular transfusions frequently show a psychosocial reaction and bad experiences. The psychosocial reaction makes thalassemia patients experience the fear of death, cannot continue their life plans, change their selfimage, self-concept, and self-confidence, change their social roles and lifestyles, and receive effects on their life. To conclude, routine transfusion and treatment impact the psychosocial reaction of thalassemia adolescent patients; each person shows different reactions depending on how they translate the pain suffered and the treatment prescribed.

\section{METHOD}

This study employed the correlation analysis method with the cross-sectional approach. This study employed the non-probability sampling method with a purposive sampling technique. Moreover, this study employed 50 respondents of adolescent thalassemia patients at RSCM Kiara.

The instrument used was a questionnaire to test the validity and reliability test. (Fitria, 2015) researched self-esteem and discovered the correlation of each statement item of the RSES self-esteem questionnaire ranging from 0.477 to 0.877 . This value was then compared with the (r) table on the significance of $5 \%$ with $\mathrm{n}=30$ by 0.361 . Because all items have a value of $\mathrm{r}$-count $>\mathrm{r}$-table, the questionnaire statements of numbers $1,2,3,4,5,6,7,8,9$, and 10 were valid and feasibly used in the study. Meanwhile,11/30/2021 3:27:00 PM Nurwulan (2017) examined family support on 15 samples. Before the trial test, there were 16 questions, then, the trial test produced 14 questions with the reliability results of 0.757 . This study concluded that the reliability test of the questionnaire of family support, including the reliability interpretation, was high.

The researchers initially tested the validity and reliability of the questionnaire to 30 adolescent thalassemia patients with the following results. 1 . The validity test signified that five statements of the family support questionnaire were not valid. They were statements number 2, 3, 9, 10, and 12 .

2. Nine statements were; they were statements number $1,4,5,6,7,8,11,13$, and 14 . Then, the reliability test was conducted by comparing the value of r-results with the value of the r-table. The value of $r$-result was the value of "Alpha." If $r$ - alpha is > r-table, the statement is reliable. The questionnaire instruments of Rosenberg's self- esteem resulted in ten statements. Four statements were invalid: numbers 1, 4, 7, and 8. Meanwhile, six statements were valid: numbers $2,3,5,6,9$, and 10 . The reliability test compared the value of r-results with the value of the r-table. The value of r-result was the value of "Alpha." If the $r$-alpha is $>r$ table, the statement is reliable. The test showed that the value of $r$-alpha (0.643) was greater than the value of the r-table $(0,367)$. This finding concludes that all statements in the questionnaire instrument were reliable.

\section{RESULTS}

The Demographic data of the respondent include age, gender and education level. Table 1 shows that the most respondents were male $(56 \%)$ than female $(44 \%)$. The majority of respondents were 17 years old and the highest level of education was junior high school. Based on table 5, it had been identified that the level of self-esteem of adolescents with thalassemia were in the middle level however they got an excellent support from their family. 
The statistical result with Spearman Rho method shows significant $\mathrm{p}$ value of $0.024(\mathrm{p}<0.05)$ and $\mathrm{r}$ value of 0.319 . The positive correlation implies that both variables are moving in same direction with weak relationship. These results are in accordance with the hypothesis that family support are related with selfesteem of thalassemia adolescents

Table 1 Distribution of Respondents, by Gender

\begin{tabular}{clcc} 
Variables & Description & Frequency & \% \\
\hline \multirow{2}{*}{ Genders } & Male & 28 & 56 \\
& Female & 22 & 44 \\
\hline \multicolumn{2}{c}{ Total } & 50 & 100.0 \\
\hline
\end{tabular}

Table 2 Distribution of Respondents, by Age

\begin{tabular}{cccc}
\hline Variables & Description & Frequency & \% \\
\hline \multirow{4}{*}{ Age in Years } & 12 & 7 & 14 \\
& 13 & 4 & 8 \\
& 14 & 8 & 16 \\
& 16 & 7 & 14 \\
& 17 & 11 & 22 \\
& 18 & 5 & 10 \\
\hline & Total & 50 & 100.
\end{tabular}

Table 3 Distribution of Respondents, by Educational Level

\begin{tabular}{lccc}
\hline Variables & Description & Frequency & \% \\
\hline \multirow{3}{*}{ Education } & Elementary School & 14 & 14 \\
& Junior High School & 18 & 32 \\
& Senior High School & 16 & 36 \\
& No School & 9 & 18 \\
\hline & Total & 50 & 100 \\
\hline
\end{tabular}

Table 4 Distribution of Respondents, by Family Support

\begin{tabular}{ccccc}
\hline Variables & Description & Frequency & $\%$ \\
\hline Family & $\bullet$ & High & 41 & 82 \\
Support & $\bullet$ & Moderate & 8 & 16 \\
& $\bullet$ & Low & 1 & 2 \\
\hline & Total & 50 & 100.0
\end{tabular}

Table 5 Distribution of Respondents, by Self- Esteem

\begin{tabular}{cccc}
\hline Variables & Description & Frequency & $\%$ \\
\hline \multirow{3}{*}{ Harga Diri } & 1. Tinggi & 13 & 26 \\
& 2. Sedang & 37 & 74 \\
& 3. Rendah & 0 & 0 \\
\hline \multicolumn{2}{c}{ Total } & 50 & 100.0 \\
\hline
\end{tabular}


Table 6 The Correlations between Family Support and Self-Esteem in Adolescents with Thalassemia

\begin{tabular}{cccc}
\hline VARIABLES & $\begin{array}{c}\text { Self-Esteem } \\
\mathrm{r} \text {-count } / \mathrm{r}(\mathrm{rho})\end{array}$ & sig $/$ - values & $\begin{array}{c}\text { Conclusion } \\
\mathrm{n}=50\end{array}$ \\
\hline Family Support & 0.319 & $\begin{array}{c}0.024 \\
(\mathrm{p}<0.05)\end{array}$ & Ha accepted \\
\hline
\end{tabular}

\section{DISCUSSION}

This study did not analyze more about the terms of demographics but described the demographic data. This stage agrees with Nurvinanda, R (2013) who revealed that different ages did not impact on separating individuals involved because the impact was probably not adolescents' self-esteem.

The result of this research showed that family support for adolescent thalassemia patients was high $(82 \%)$ because the patients were still young and need accompaniment from their families. This finding agrees with the theory of Friedman (2017) that the internal and external sources of family support for adolescent thalassemia patients were appropriate. Smet theory (2002) states that family support will improve adolescent thalassemia patients' physical health, stress reaction management, productivity, and psychological welfare. Adolescent thalassemia patients seemed more confident and felt peace during the mentoring.

However, the family support was still low (2\%) because the adolescents perceived that they were grown up and had a friend, another patient, whose schedules of regular medical check-ups were the same. Thus, they made appointments. Thalassemia is a genetic disease and inherited by both parents. Therefore, when adolescent thalassemia patients visited the hospital, they required additional support from Thalassemia mates, not from their parents. This finding agrees with Nurvinanda, R (2013) who conducted qualitative research and investigated eight caregiver participants. Nurvinanda, R (2013) mentioned in her abstract that the nursing management for a child with major thalassemia focused on family teaching and family support. The participants' experience with for caring a child with beta major thalassemia denoted two sub-themes of the family support theme. These sub-themes were internal and external family support.

This study investigated the self-esteem variable of 50 young thalassemia respondents and discovered 37 people (74\%) had moderate self-esteem, and none of the respondents had low self-esteem. (Morris, 2016) postulates that self-esteem is a positive or negative evaluation of yourself. Many adolescent thalassemia patients have high and moderate self-esteem. This condition interprets that they evaluate themselves in positive directions and the values are in normal ranges. The theory of (Stuart, 2016) postulates that an individual self-esteem assessment is based on how well their behavior is and matches with an ideal self. This postulation signified that the adolescent thalassemia patients with high and moderate self- esteem assessed themselves as suitable to the ideal self. They had great suitability of the self-concept and ideal self because they had a high level of high self-esteem. Despite their strengths and weaknesses, their confidence was in a normal value of self-esteem. This finding agrees with Mulikat and Deborah (2019), who deploy that individuals react to discomfort in reverse by considering their personality and life stages.

This study rejected the notion proposed by (Mariani, 2014) that children with thalassemia experience different feelings from others and have low self-esteem. The respondents of this research were adolescent thalassemia patients, and they did not feel or judge themselves with low self-esteem.

Another previous study by (Sipahutar, 2009) investigated 30 respondents with chronic renal failure in the Angsok room at RSUP (central general hospital) Sanglah Denpasar by using the Rosenberg self-esteem scale. The study found that $66.7 \%$ of the participants had moderate self- esteem, and this number is the highest. This finding is similar to that of this research because 50 respondents ( $74 \%$ ) had moderate selfesteem.

The correlations between family support and self-esteem in adolescent with Thalassemia This study revealed a low relationship or correlation between two variables: family support of all existing items (emotional, instrumental informational, and award support) and self-esteem in adolescent thalassemia patients. Moreover, the study found that the correlation coefficient was positive. This finding indicates unidirectional meaning and states that a high level of family support for adolescent thalassemia patients will create a high level of their self-esteem.

In this study, the correlation coefficient between the variable of family support and the variable of Rosenberg self-esteem showed the value of $r=0.319$. This figure denoted a weak relationship between the 
two variables. Unlike the research by (Lestari, 2013) who discovered the moderate relationship because of the value of $r=0.419$. However, the two investigations have a similarity, i.e., the higher the family support is, the higher the self-esteem of adolescent thalassemia and leprosy patients will be. This similarity shows that family support and self-esteem have similarly positive values and are interconnected. The researcher agreed with (Lestari, 2013) stating that family support is pivotal to increase an individual's self- esteem, and support received by individuals highly depends on the support providers (Nurmalasari \& Putri, 2015).

This research found that family support is related to teenagers' self-esteem. The finding agrees with the theory of Boeree (2006), postulating that two main sources are affecting an individual's self- esteem: selfappreciation by believing that an individual feels safe with his situation, valuable, and powerful, and (2) other-appreciation by relating the significance to acceptance, attention, and affection shown by the environment. This statement is in line with Sarason in (Nurmalasari \& Putri, 2015), asserting that a high influence of social support will let individuals experience a better life, higher self-esteem, and more positive views on life. This statement means that subjects' high self-esteem occurs because they have high social support, such as the influence of feeling comfort felt by individuals when they are in the environment and when being cared for by others.

Thalassemia is a disease inherited from birth. The disease will be worse if it is less significantly treated or cared for by family or medical assistance. Such a condition will impact patients' physical and psychological growth. Like lupus disease, thalassemia is caused by immunological abnormalities, brings lifetime impacts, and requires regular treatment. The researchers found thalassemia sufferers diagnosed with lupus, and this disease brought major physical and psychical changes to lupus patients. This condition often raises psychological effects, especially negative self- esteem sufferers (Nurmalasari \& Putri, 2015). Therefore, social support is necessary to maintain patients' self-esteem and positiveness. Finally, individuals can adapt to the disease.

This research found that $41 \%$ of adolescent thalassemia patients had high family support, while $37 \%$ had moderate self-esteem. These findings agree with the theory of (Morris, 2016) asserting three aspects of self-esteem: (1) the physical self-esteem associated with individuals' physical conditions, (2) social selfesteem associated with individuals' ability to socialize, and (3)self-esteem performance associated with individuals' ability and achievements.

\section{CONCLUSION}

Adolescence is a period when adolescents experience an identity crisis, especially self- esteem. Such a crisis must be solved before they reach 18 years old or amidst 18 years old. Therefore, they can continue to resume the life task excellently and have a consistent sense of self or an internal standard to assess their primary self-meaningfulness in life. Thus, they will not experience identity confusion. This study concludes that there is a low correlation or relationship between family support and self- esteem of adolescent thalassemia with the $p$-value $=0.024(\mathrm{p}<0.05)$ and the value of $r=0.319$. However, the correlation coefficient is positive. This finding states that a higher level of family support for adolescent thalassemia sufferers will bring them a higher level of self-esteem.

Adolescence is marked by emotional socialization development, and thalassemia adolescents realize to successfully identify themselves, especially regarding self-esteem assessment as thalassemia adolescents). They require support from their environment, such as parents, family, friends, and others to survive in facing the limitations.

\section{REFERENCE}

Albaroroh. (2016). Interaksi Sosial di Panti Asuhan dalam Membentuk Tingkah laku Anak (Studi di Balai Rehabilitasi Sosial dan Pengasuhan Anak (BRSPA) Sleman, Yogyakarta).

Universitas Isam Negeri Sunan Kalijaga.

Dewijayanti, R. (2018). Hubungan Antara Self Esteem dengan Psychological Well Being pada Pasien Thalassemia Beta mayor Usia Dewasa Awal di RS $\mathrm{X}$ Bandung. UNISBA. http://karyailmiah.unisba.ac.id/index. php/psikologi/article/view/11705

Fitra, R. (2015). Hubungan Harga Diri Mahasiswa dengan Kemampuan Aktualisasi Diri dalam Proses Belajar Metode Seven Jump di Fakultas Ilmu Keperawatan UIN Syarifhidayatullah Jakarta. 115.

Lestari. (2013). Hubungan Dukungan Keluarga dengan Harga Diri Penderita Kusta Rawat Jalan di Rumah 


\section{Jurnal Mitra Kesehatan (JMK)}

Sakit Rehatta Donorojo Jepara. STIKes Telogorejo.

Mariani, D. (2014). Analisis Faktor yang Mempengaruhi Kualitas Hidup Anak Thalassemia Beta Mayor. Jurnal Keperawatan Indonesia, 17. http//:jki.ui.ac.id/index.php/jki/articl e/view/375/499

Morris, R. (2016). Rosenberg Self-Esteem Scale. Princeton University Press.

Mulyani, \& Fahrudin, A. (2011). Reaksi Psikososial Terhadap Penyakit Dikalangan Anak Penderita Thalassemia. https://ejournal.kemsos.go.id/index. php/Sosioinforma/article/view/52

Nurmalasari, Y., \& Putri, D. E. (2015). Dukungan Sosial Dan Harga Diri Pada Remaja Penderita Lupus. $8(1), 6$.

Sipahutar, I. E. (2009). Gambaran Harga Diri Pasien Gagal Ginjal Kronik di Ruang Angsok RSUP Sanglah Denpasar. Politeknik Depkes Denpasar.

Stuart. (2016). Prinsip dan Praktik Keperawatan Jiwa. Elsevier.

Wahidiyat. (2018). Nurse Class Thalassemia. 